\title{
Effects of climatic variability and human activity on runoff in the Loess Plateau of China
}

\author{
by Yang Zhao ${ }^{1}$ and Xinxiao $\mathrm{Yu}^{1}$,*
}

\begin{abstract}
The Loess Plateau in north-central China has a long history of human activities. As a result of climate change, deforestation and sparse vegetative cover, the region suffers from water shortages and severe soil erosion, significantly influencing efforts for sustainable social development. In order to understand the impacts of climatic variability and human activities on runoff and other hydrological factors in this region, the Luoyugou catchment and its paired catchments (Qiaozidong and Qiaozixi) were selected. Statistical analysis indicated precipitation did not vary significantly whereas the annual runoff decreased from 1986 to 2008, with an abrupt change in 1994. Actual evapotranspiration (AET) increased slightly but not significantly. A comparison of runoff in the paired catchments showed land use changes reduced runoff by more than $38 \%$ under the same rainfall conditions. Human activities were the strongest contributor to changes in runoff and AET, at $67 \%$ and $90 \%$ respectively, while the remaining contributor was climate variation. The influence of various human activities on runoff is quite different, and soil-water conservation initiatives have a greater impact on runoff (about $41 \%$ ). Thus, human activities were the primary reason for the reduction in runoff in the study catchment compared to climate. Greater emphasis should be given to afforestation and soil-water conservation measures.
\end{abstract}

Keywords: runoff, climate change, human activities, Loess Plateau

\section{RÉSUMÉ}

Le Plateau de Loess situé dans le centre-nord de la Chine est depuis longtemps marqué par les activités humaines. En raison du changement climatique, du déboisement et d’un couvert végétal clairsemé, la région subit des périodes de sécheresse et une érosion des sols importante, ce qui entrave grandement les efforts en vue d'un développement social durable. Pour évaluer les conséquences de la variabilité climatique et des activités humaines sur le ruissellement et les autres facteurs hydrologiques de la région, on a jumelé trois bassins hydrographiques soit celui de Luoyugou et ses témoins les bassins Qiaozidong et Qiaozixi pour y mener une étude. Les analyses statistiques ont révélé que le ruissellement avait diminué entre 1986 et 2008, avec un changement marqué en 1994, bien que les précipitations n’aient pas varié de façon significative. Lévapotranspiration réelle (EtR) a connu une hausse légère, mais pas significative. Une comparaison du ruissellement dans les bassins jumelés à létude a démontré que les changements d’affectation territoriale ont réduit de plus de 38 \% le ruissellement dans les mêmes conditions pluviométriques. Les activités humaines constituaient le facteur le plus important de changement du ruissellement ainsi que l'EtR, soit, respectivement, de $67 \%$ et de $90 \%$, le changement climatique expliquant le reste de cette variation. Linfluence des différentes activités humaines était très inégale et les projets de conservation de l'eau et des sols avaient la plus grande influence sur le ruissellement (environ $41 \%$ ). Les activités humaines représentaient donc la principale cause de réduction du ruissellement dans le bassin sous étude par rapport au climat. Il faudrait donc mettre davantage l'accent sur le reboisement de terres en friche et sur les mesures de conservation de leau et des sols.

Mots clés : ruissellement, changement climatique, activités humaines, Plateau de Loess

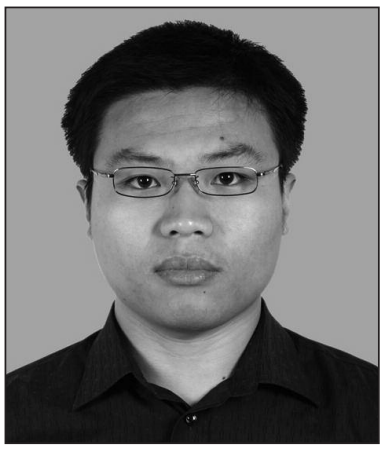

Yang Zhao

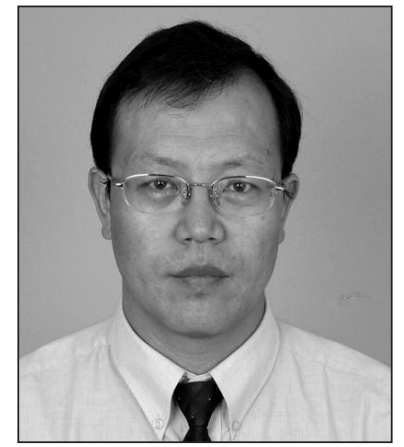

Xinxiao Yu

${ }^{1}$ College of Soil and Water Conservation, Beijing Forestry University, Beijing, China.

*Corresponding author. E-mail: yuxinxiao111@126.com 


\section{Introduction}

Climate change and human activities are key factors considered responsible for changes in hydrological dynamics of water catchments (Asbjornsen et al. 2011). Climate change has resulted in the rise of atmosphere temperatures and modified the pattern of precipitation and evapotranspiration, which has directly led to altered regional hydrological cycles (Li et al. 2008). Climatic variables, especially rainfall, largely determine the runoff volume of a catchment (Wang et al. 2009). Changes in land use and land cover also causes significant impacts on hydrology by affecting the characteristics of runoff, evapotranspiration, sediment, soil moisture, infiltration and groundwater recharge (Gabris et al. 2003). Current hydrologic models and statistical methods are usually applied to study the effects of climate variations and human activities on catchment hydrological processes (Chen and Chen 2004). Traditional statistical methods require data from long-term monitoring, which are often not available. More importantly, these methods lack a physical basis and decrease the degree of computational precision (Zhan et al. 2011). Hydrological models also require considerable data that may be unavailable, such as spatial data representing landscape structure and catchment properties.

An alternative method proposed by Milly and Dunne (2002) to describe the first-order effect of changes in precipitation and potential evapotranspiration on runoff has attracted wide attention. It may be used to study hydrological responses to changes in climate and land use and enables the separation of the effect of climate on runoff from that of land use changes caused by human activities (Li et al. 2010). In order to further analyze the effect of land use changes on runoff and evapotranspiration, a paired catchments approach and separation evaluation methods have been used in this study.

The Loess Plateau in north-central China covers approximately $400000 \mathrm{~km}^{2}$ and is the world's largest. "Loess" refers to fine-grained, wind-deposited, yellowish alluvium soil. The region is highly erosion-prone and the most vulnerable ecological environment in the country. It is characterized by its unique gullied landscape. According to hydrological records, approximately $90 \%$ of the sediment of the Yellow River comes from the Loess Plateau (Tang and Chen 1990). Since the latter half of the 20th century, this region has experienced a warming and drying trend (Liu et al. 2006). In addition, severe ground-water exploitation has accelerated water shortages caused by climate variations and human activities. This has had a significant negative impact on the social and economic development in this region. Therefore, it is imperative to understand and quantify the influence and relative importance of climate variations and human activities.

Luoyugou, a typical catchment on the Loess Plateau, was selected as the study area. It is vulnerable to climate changes and has been affected by human activities over the past 30 years. With a worsening water crisis, it has become important to assess the impact of climate variation and human activities on hydrological factors and to use this information to develop strategies for ecological restoration and sustainable regional development. Therefore, the purpose of this study is to separate the effects of climate variability and human activities on runoff and AET in a typical loess catchment. Specifically, the following will be addressed: (1) to detect trends and changes in precipitation $(\mathrm{P})$, potential evapotranspiration (PET) , runoff (R) and actual evapotranspiration (AET); (2) to estimate the contribution of climate change and human activities on the change of R and AET; (3) to understand the influence of different forms of human activities on runoff variation.

\section{Materials and Methods Study area}

The Luoyugou catchment and its paired watersheds of Qiaozidong and Qiaozixi, located south of Tianshui City, Gansu Province in northwestern China, have an area of approximately $73 \mathrm{~km}^{2}$. The area is part of the third sub-region of the Loess Plateau. The gully system is feather-shaped and ranges from 1200 to $1895 \mathrm{~m}$ in elevation (Fig. 1). Average temperatures are above $10^{\circ} \mathrm{C}$ and the area has a continental monsoon climate, changing from semi-arid to semi-humid over the year with an annual precipitation of approximately

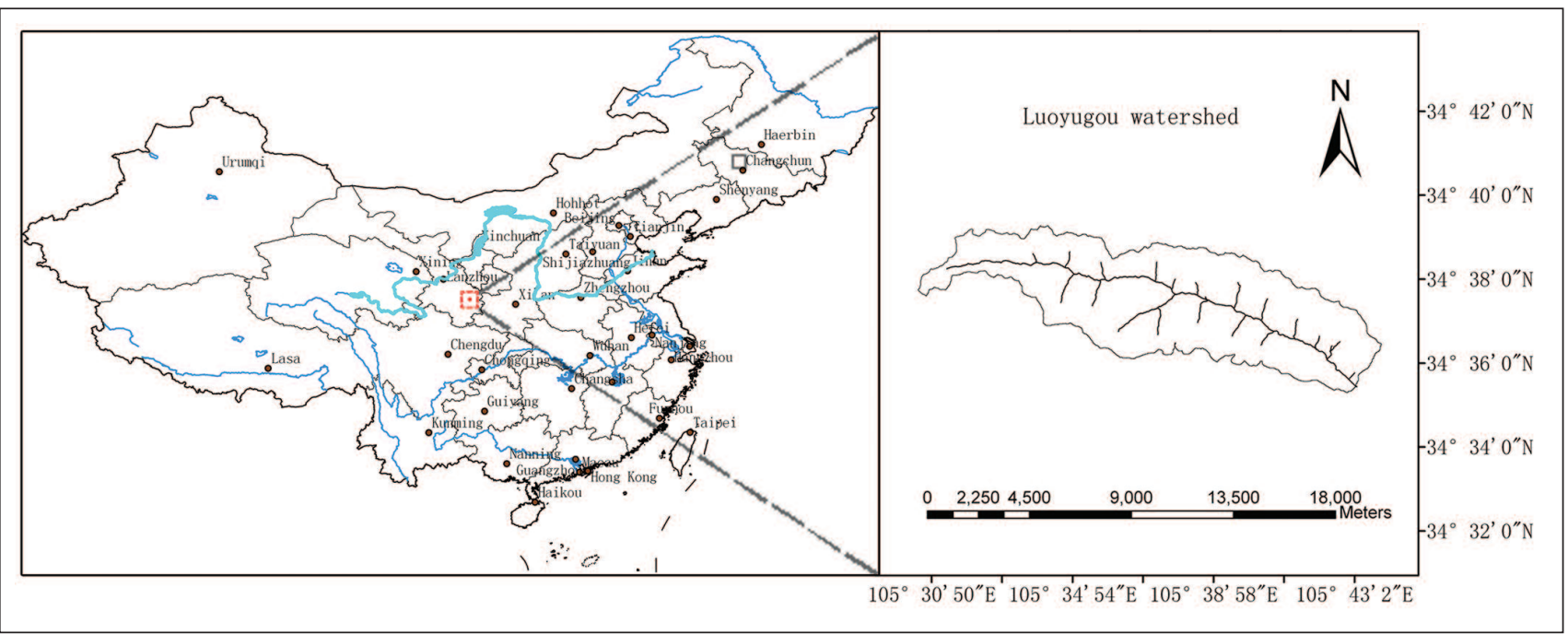

Fig. 1. Location of watersheds under study. 


\begin{tabular}{|c|c|c|c|c|c|c|c|c|}
\hline Name & $\begin{array}{l}\text { Area } \\
\left(\mathbf{k m}^{2}\right)\end{array}$ & $\begin{array}{c}\text { Is there } \\
\text { artificial } \\
\text { disturbance? }\end{array}$ & $\begin{array}{c}\text { Length of } \\
\text { Watershed } \\
(\mathbf{k m})\end{array}$ & $\begin{array}{c}\text { Slope in } \\
\text { Gully } \\
(\%)\end{array}$ & $\begin{array}{l}\text { Relative } \\
\text { height } \\
\text { difference } \\
\text { (m) }\end{array}$ & $\begin{array}{c}\text { Annual } \\
\text { erosion } \\
\text { modulus } \\
\text { from } \\
1986 \text { to } 2004 \\
\left(\mathrm{t} / \mathrm{km}^{2}\right)\end{array}$ & $\begin{array}{l}\text { Vegetation } \\
\text { cover of } \\
2004 \\
(\%)\end{array}$ & $\begin{array}{l}\text { Main land use } \\
\text { types of } 2004\end{array}$ \\
\hline Qiaozidong & 1.27 & YES & 2.13 & 20.75 & 377 & 2310.4 & 39.86 & $\begin{array}{c}\text { Forest }(58.8 \%) \\
\text { and orchards }(28.9 \%)\end{array}$ \\
\hline Qiaozixi & 1.10 & $\mathrm{NO}$ & 2.22 & 21.47 & 377 & 4270.6 & 21.79 & $\begin{array}{l}\text { Orchards (38.3\%) } \\
\text { and sloping land (36.4\%) }\end{array}$ \\
\hline
\end{tabular}

$550 \mathrm{~mm}$. More than $60 \%$ of the year's rainfall is during the June to September monsoon season. Soil types are mount gray loamy, loess gray, and loess loamy soils (Yu et al. 2009). The Qiaozidong watershed is a half-scallop shape with an area of $1.27 \mathrm{~km}^{2}$, and the Qiaozixi watershed has a feathering pattern over an area of $1.10 \mathrm{~km}^{2}$. There are no control measures for soil and water conservation in Qiaozixi. Qiaozidong has controls and has similar natural conditions to Qiaozixi. The main characteristics of Qiaozidong and Qiaozixi are listed in Table 1.

\section{Land use data}

Four satellite images (Landsat TM 1986, 1995, 2001, 2008) were obtained from Institute of Geographic Sciences and Natural Resources Research, Chinese Academy of Science (CAS). Using ArcGIS9.3, land use structure and land cover change of the Luoyugou catchment were obtained through overlay analysis for the four study periods: 1986, 1995, 2001 and 2008.

\section{Hydrological data}

Annual runoff data were available from the hydrological station and precipitation was measured by nine automatic rain gauges located within Luoyugou. Air temperature and other meteorological factors including relative humidity, solar radiation and wind speed were measured at a local meteorological station one $\mathrm{km}$ outside the study watershed. Potential evapotranspiration (PET) was calculated with meteorological data for the period using the Penman-Monteith equation (Allen et al. 1998).

\section{Data Analysis}

The study involved: (1) statistic analytical methods including nonparametric Kendall's trend test (Hirsch et al.1982), moving t-tests, double-mass curve analysis and Normalization Method $(\mathrm{y}=(\mathrm{x}-$ MinValue $) /($ MaxValue - MinValue $))$ from Baidubaike (Baidu, Inc. [undated]) to detect trends of runoff and climatic variables; (2) a paired catchment approach to explore the effects of human activities on runoff; (3) multiyear average water balance model and separation evaluation method to determine the rates of change in climate and human activities on runoff and AET, respectively.

\section{Multi-year average water balance model}

To estimate the impact of climate change and human activities on runoff, a change in observed mean annual runoff $\Delta Q^{\text {tot }}$ may result from climate variability $\left(\Delta Q^{- \text {clim }}\right)$ and human activities ( $\left.\Delta Q^{- \text {ha }}\right)$ (Li et al. 2007, Zhang et al. 2009). Therefore $\Delta Q^{\text {tot }}$ may be estimated by the following:

$$
\text { [1] } \Delta Q^{\text {tot }}=\Delta Q^{-\mathrm{clim}}+\Delta Q^{-\mathrm{ha}}
$$

$\Delta Q^{\text {tot }}$ is differences of annual mean runoff between two periods at the "inflection point", as follows:

$$
\text { [2] } \Delta Q^{\text {tot }}=\overline{Q_{2}}-\overline{Q_{1}}
$$

where $\overline{Q_{1}}$ and $\overline{Q_{2}}$ are average annual runoff of the two periods before and after the "inflection point".

Changes in precipitation and potential evapotranspiration may lead to changes in the water balance (Li et al. 2007). A change in mean annual runoff $\left(\Delta Q^{\text {-dim }}\right)$ may be determined by (Milly and Dunne 2002):

$$
\text { [3] } \Delta Q^{- \text {clim }}=\beta \Delta P+\gamma \Delta E_{0}
$$

where $\Delta P$ and $\Delta E_{0}$ are changes in precipitation $(\mathrm{P})$ and potential evapotranspiration (PET); $\beta$ and $\gamma$ are the reflection of runoff to precipitation and PET. According to Zhang et al. (2001), long-term average evapotranspiration and sensitivity coefficients may be estimated by:

$$
\begin{aligned}
& \text { [4] } \frac{E}{P}=\frac{1+W\left(E_{0} / P\right)}{1+W\left(E_{0} / P\right)+\left(E_{0} / P\right)^{-1}} \\
& \text { [5] } \beta=\frac{1+2 X+3 W X^{2}}{\left(1+X+W X^{2}\right)^{2}} \\
& \text { [6] } \gamma=-\frac{1+2 W X}{\left(1+X+W X^{2}\right)^{2}}
\end{aligned}
$$

where $E$ is the actual evapotranspiration with a common unit of $\mathrm{mm}$; $\mathrm{x}$ is the index of dryness and equal to $E_{0} / P$; $w$ is a integrative parameter related to vegetation type and calculated by weighting the area with each land type.

\section{Separation evaluation method}

Separation evaluation was used to examine the impacts of climatic variability and land use change on AET. It is critical to determine the inflection point in the evapotranspiration 
record using double-mass curve analysis (DMC) of Bonat et al. 1997. By plotting the accumulation of two quantities the slope of the straight line will represent the constant of proportionality between the two quantities. An inflection point is a point on a curve at which the curvature or concavity changes sign from plus to minus or minus to plus. An inflection point in the slope indicates that factors other than precipitation affect AET. According to the inflection point of the curve, the study is divided into two periods, the "base period" influenced slightly by human activities and the "compared period" marking significant changes in land use by human activities and takes the inflection point as the cut-off to reflect the effect of land use change on AET. The method after Wang 2006 and Wang, G.Q. et al. 2008 is:

$$
\text { [7] } \Delta S^{\prime}=Q_{\mathrm{S} 2}-Q_{\mathrm{S} 1}=\Delta S_{1}+\Delta S_{2}
$$

[8] $\Delta S_{1}=Q_{\mathrm{s} 2}-Q_{\mathrm{s} 2}^{\prime}$

$$
\text { [9] } \Delta S_{2}=Q_{\mathrm{S} 2}^{\prime}-Q_{\mathrm{S} 1}
$$

where $\Delta S$ is the total change in $A E T, Q_{S 1}$ and $Q_{S 2}$ represent the AET in the base period and compared period, and $\Delta S_{1}$ and $\Delta S_{2}$ are changes in AET by human activities and precipitation, respectively. $\mathrm{Q}_{\mathrm{S} 2}$ is the simulation AET based on the P - AET curve.

\section{Results and Discussion}

Average annual precipitation in the Luoyugou catchment was $528 \mathrm{~mm}$, ranging from $322 \mathrm{~mm}$ to $810 \mathrm{~mm}$. Annual precipitation showed a slight decrease of $0.08 \mathrm{~mm}$ per year (Fig. 2A). Combined with the result of nonparametric Kendall's trend test and moving t-test, no inflection point was detected in the precipitation record (Fig. 3A and Fig. 4A).

Under the influence of human activities and warmer and drier climates, annual runoff showed a significant decreasing trend with a mean value of $20 \mathrm{~mm}$ (Fig. 2A). Nonparametric Kendall's trend test indicated that the change in annual runoff occurred in 1992 (Fig. 3B). Combined with the moving t-test (Fig. 4B), one inflection point in 1994 was identified. With this result, the annual runoff study period may be divided into two parts: a base period (1986-1994) and a compared period (1995-2008).

Annual potential evapotranspiration showed a slight increase (Fig. 2B). No change points occurred in the study period (Fig. 3C and Fig. 4C). Annual evapotranspiration from the water balance model (Zhang et al. 2001) showed a slight increase from 1986 to 2008 (Fig. 2B). Using Kendall's trend test and moving $\mathrm{t}$-test, no break point was found in the AET record (Fig. 3D and Fig. 4D).

\section{Land use changes}

According to national land use classification combined with land use on hills and gully regions of the Loess Plateau, land use was categorized into seven types: sloping farmland, terrace, forest, grassland, orchard, river and settlements.

Based on ArcGIS 9.3, land use in different periods was obtained (Table 2). Sloping farmlands, terraces and forests, accounting for over $80 \%$ of the total area in the study period,

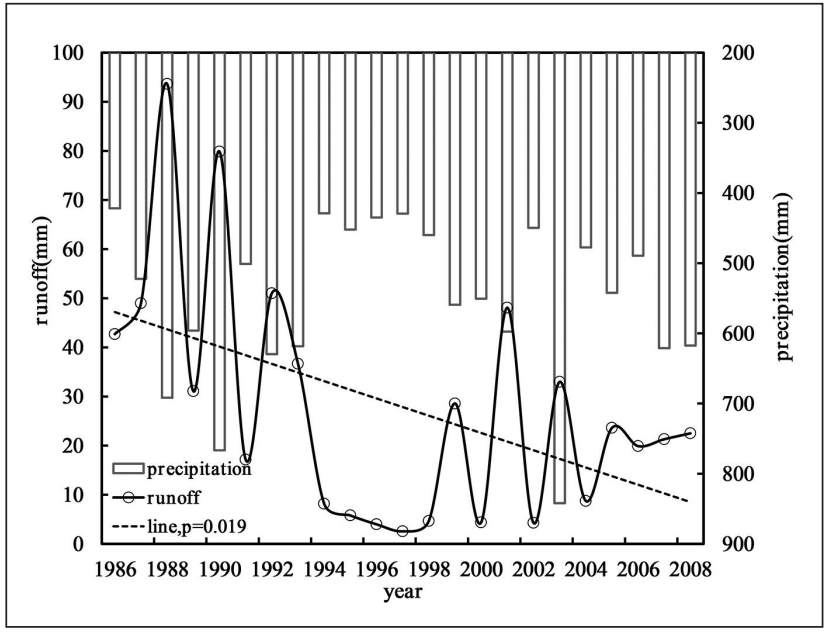

Fig. 2A. Changes in precipitation and runoff from 1986 to 2008.

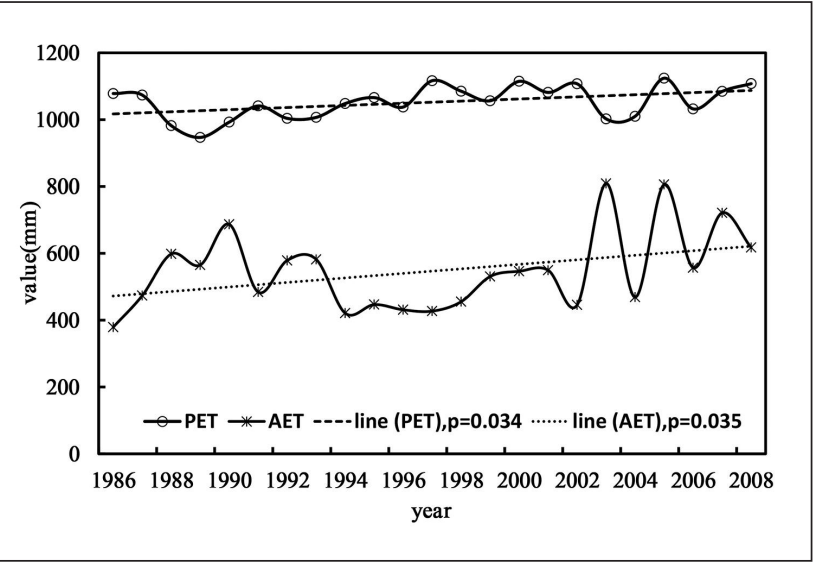

Fig. 2B. Changes of PET and AET from 1986 to 2008.

dominated the area. Large-scale (about 75\%) sloping farmlands were converted to terraces from 1986 to 1995. Policy and economic impacts were the driving force behind the extreme land use change (Madelene and Chen 2006). Forested lands increased by over $28 \%$ compared with 1986 levels, which coincide with the Slope Land Conversion Program in the Loess Plateau (Ma et al. 2008). Orchards increased after 2001 by $106 \%$. This expansion was due to local farmers planting cherry trees to improve their incomes. River and settlement areas changed little over the study period. From 1986 to 1995, forest, grassland and terrace areas increased at a relative high rate while sloping farmland decreased. The decrease in runoff in the 1990s onwards is possibly due to changes in land use observed during the same period.

Effects of climate variations and human activities on runoff Fig. 5 compares runoff modulus for the paired catchments (Qiaozidong and Qiaozixi) under similar rainfall conditions. Runoff in Qiaozixi is significantly lower than in Qiaozidong although rainfall levels are the same. The runoff modulus is reduced from $12 \%$ to $79 \%$ with an average reduction of $38 \%$. This reduction is most likely due to land use changes and vegetation cover. 

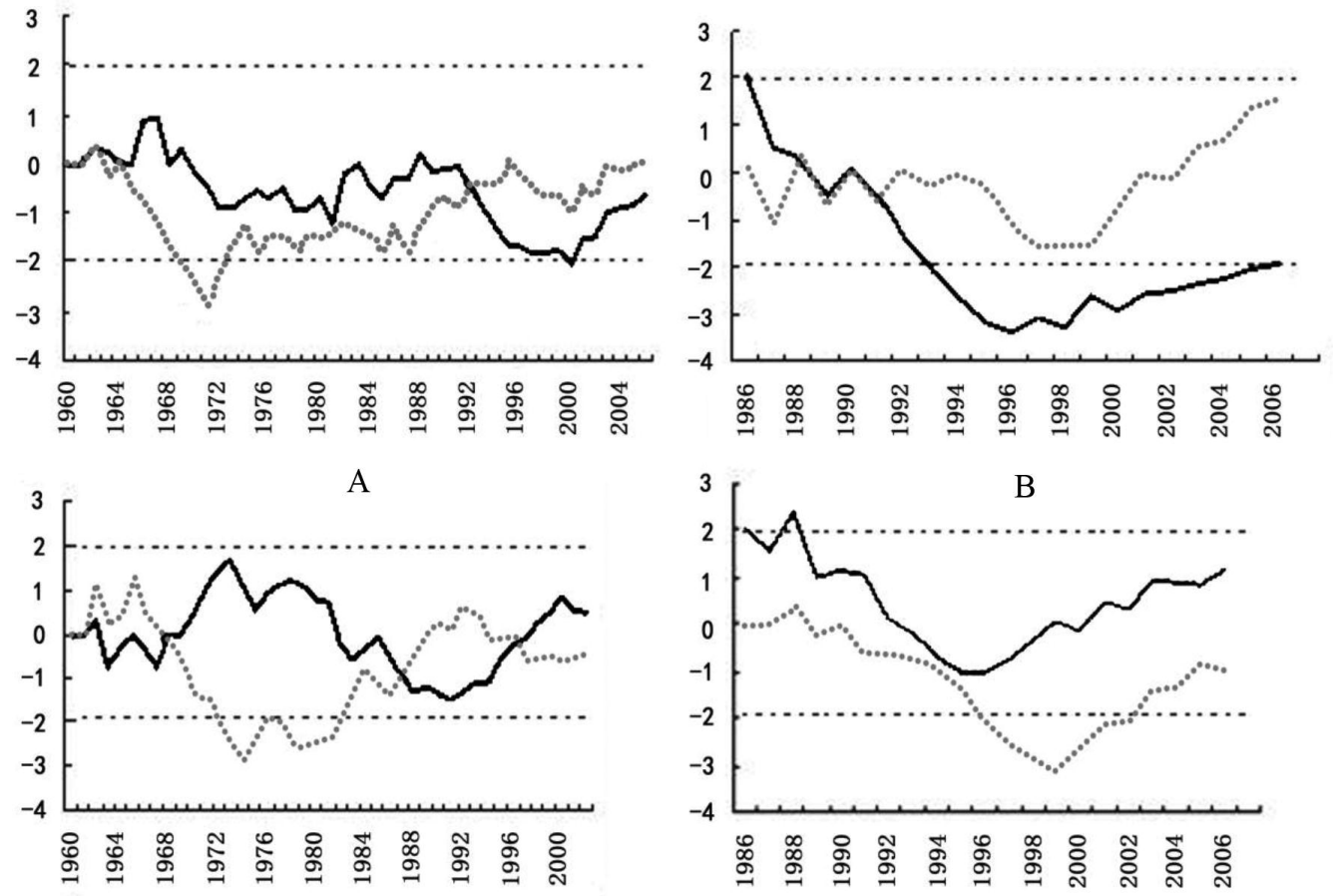

$\mathrm{C}$

$Z 1 \cdots \cdots \cdots \cdot Z 2 \cdots \cdots \cdot \mathrm{a}=0.05$

D

Fig. 3. Nonparametric Kendall's trend test of $P(\boldsymbol{A}), \mathrm{R}(\mathbf{B}), \mathrm{PET}(\mathbf{C})$ and AET (D). Dark line C1; grey lines C2; dotted line significance level at 0.05 .
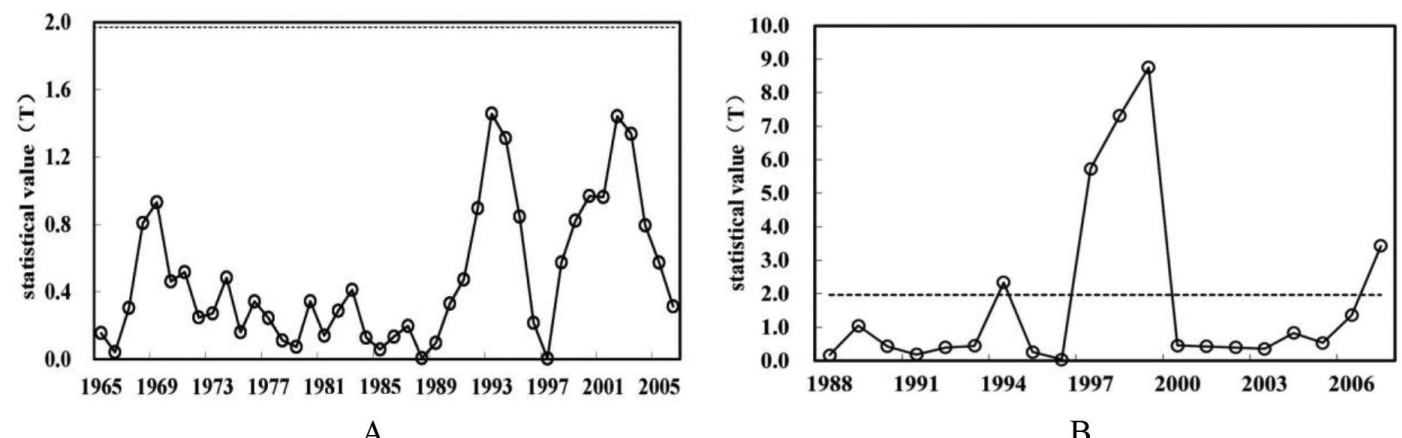

A

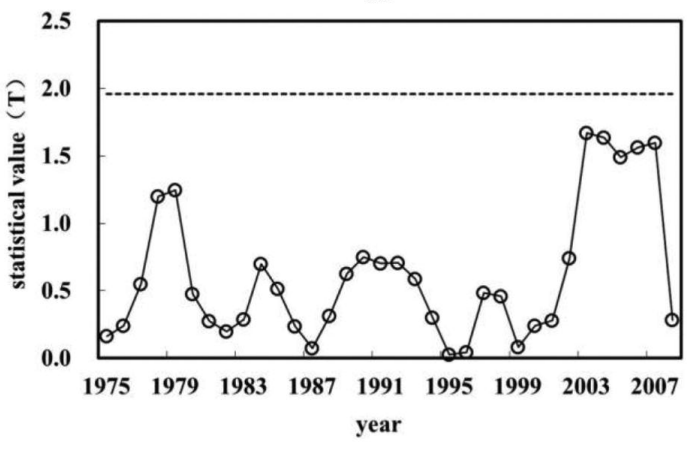

$\mathrm{C}$

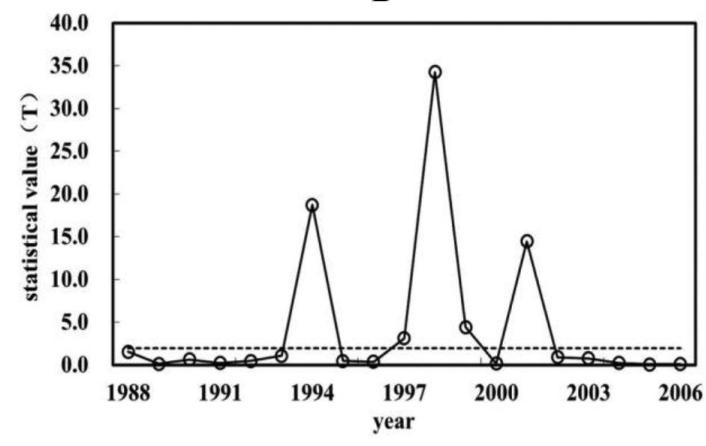

$\mathrm{D}$

Fig. 4. Moving t-test of $P(\boldsymbol{A}), R(\mathbf{B}), \operatorname{PET}(\mathbf{C})$ and AET (D). Dotted line represents significance level at 0.05 . 
Table 2. Area and percentage of land use types in Luoyugou watershed

\begin{tabular}{|c|c|c|c|c|c|c|c|c|}
\hline \multirow[b]{2}{*}{ Land type } & \multicolumn{2}{|c|}{1986} & \multicolumn{2}{|c|}{1995} & \multicolumn{2}{|c|}{2001} & \multicolumn{2}{|c|}{2008} \\
\hline & $\begin{array}{c}\text { Area } \\
\left(\mathrm{km}^{2}\right)\end{array}$ & $\begin{array}{c}\text { Percentage } \\
(\%)\end{array}$ & $\begin{array}{c}\text { Area } \\
\left(\mathbf{k m}^{2}\right)\end{array}$ & $\begin{array}{c}\text { Percentage } \\
(\%)\end{array}$ & $\begin{array}{c}\text { Area } \\
\left(\mathbf{k m}^{2}\right)\end{array}$ & $\begin{array}{c}\text { Percentage } \\
(\%)\end{array}$ & $\begin{array}{c}\text { Area } \\
\left(\mathrm{km}^{2}\right)\end{array}$ & $\begin{array}{c}\text { Percentage } \\
\text { (\%) }\end{array}$ \\
\hline Slope farmland & 49.23 & 67.63 & 11.23 & 15.43 & 11.18 & 15.36 & 9.49 & 13.04 \\
\hline Terrace & 3.09 & 4.25 & 39.05 & 53.65 & 39.03 & 53.62 & 39.76 & 54.62 \\
\hline Forest & 7.89 & 10.84 & 9.97 & 13.70 & 10.06 & 13.82 & 10.13 & 13.92 \\
\hline Grassland & 6.76 & 9.29 & 6.63 & 9.11 & 6.59 & 9.05 & 5.05 & 6.94 \\
\hline Orchard & 2.07 & 2.84 & 2.17 & 2.98 & 2.18 & 2.99 & 4.27 & 5.87 \\
\hline River & 1.06 & 1.46 & 1.06 & 1.46 & 1.06 & 1.46 & 0.84 & 1.15 \\
\hline Settlements & 2.69 & 3.70 & 2.69 & 3.70 & 2.69 & 3.70 & 3.25 & 4.46 \\
\hline Total & 72.79 & 100.00 & 72.79 & 100.00 & 72.79 & 100.00 & 72.79 & 100.00 \\
\hline
\end{tabular}

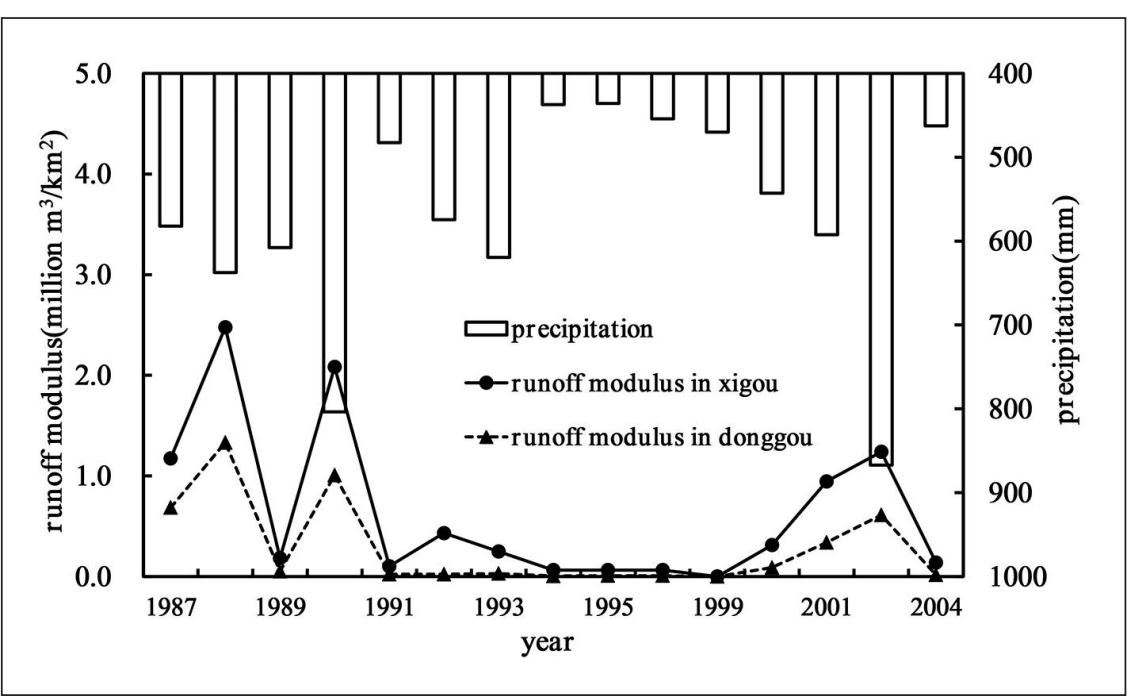

Fig. 5. Comparison on runoff in single rainstorm.

Table 3. Contribution rate of climate change and land-use changes on runoff

\begin{tabular}{lcccccc}
\hline Period & $\begin{array}{c}\boldsymbol{P} \\
(\mathbf{m m})\end{array}$ & $\begin{array}{c}\boldsymbol{E}_{\mathbf{0}} \\
(\mathbf{m m})\end{array}$ & $\begin{array}{c}\boldsymbol{Q} \\
(\mathbf{m m})\end{array}$ & $\begin{array}{c}\Delta Q^{\text {tot }} \\
(\mathbf{m m})\end{array}$ & $\begin{array}{c}\Delta Q^{-\mathrm{cliz}} \\
(\mathbf{\%})\end{array}$ & $\begin{array}{c}\Delta Q^{-\mathrm{ha}} \\
(\mathbf{\%})\end{array}$ \\
\hline $1986-1994$ & 541.1 & 1032.72 & 35.14 & & & \\
$1995-2008$ & 606.05 & 1073.15 & 20.10 & 15.14 & 33.10 & 66.90 \\
\hline
\end{tabular}

In order to analyze the impacts of climate variation and land use changes on runoff, runoff was divided into two parts according to the inflection point of the runoff record: a baseline period (1986-1994), representing runoff under more natural conditions and a compared period (1995-2008), representing runoff under the impact of climate change and human activities. Based on equations 1, 2 and 3, the effects of climate change and human activities on runoff were calculated. The model parameter $w$ was determined according to 1986 land use data. Table 3 shows the results calculated by the multi-year average water balance model and indicates that cli- mate change accounts for $33 \%$ of the observed change in mean annual runoff and human activities for $67 \%$.

General linear regression analysis showed that runoff was positively correlated with $\mathrm{P}\left(R^{2}=0.35, p=0.003<\right.$ $0.05)$ and negatively correlated with $\mathrm{T}$ $\left(R^{2}=0.30, p=0.006<0.05\right)$ (Fig. 6). From the size of the correlation coefficient, the interaction of $\mathrm{P}$ and $\mathrm{T}$ influences the reduction of runoff while precipitation has a greater influence on runoff compared to temperature. Normalization method applied to further analyze the impact of $\mathrm{P}$ and $\mathrm{T}$ on runoff found that changes in runoff and rainfall were similar, which indicates the change of precipitation had a greater influence on runoff than temperature (Fig. 7).
Effect of different forms of human activities on runoff

The above results demonstrate that human activities exert a dominant influence upon runoff decline in the Luoyugou watershed compared to climate. In order to analyze the effect of different forms of human activities, data including land use, water conservancy projects and annual water consumption during the period of 1986-2008 were collected from the Water Resources Bureau of Tianshui City.

Effect of the Slope Land Conversion Program on decreasing runoff

In the Luoyugou watershed, especially after 1990, large-scale sloping farmlands were converted to terraces and forests. According to the data (Table 2), sloping land, a major source of sediment yield, decreased by $39.7 \mathrm{~km}^{2}$ and areas of forest and terraces increased by $2.2 \mathrm{~km}^{2}$ and $36.7 \mathrm{~km}^{2}$ from 1986 to 2008, respectively. Based on related research (Liu 1978, Wu and Pei 2002), the mean stream flow of sloping land area was about $80 \%$ higher than that of terraces and 37\% lower than that of the sloping land area in the Loess Plateau. Using the data above and eq. 10, decreases in runoff can be attributed to about $30 \%$ of the Slope Land Conversion Program in the Luoyugou watershed. The formula is: 


$$
\text { [10] } S=\sum_{i=1}^{n} A_{i} \times I_{R}
$$

where $S$ is the contribution ratio of the effect of the Slope Land Conversion Program on runoff, $A_{i}$ the area of terrace or forest transferred from the sloping area over the study period, and $I_{R}$ the intercept capacity of terrace or forest on runoff compared with the sloping land.

Impacts of soil and water conservation measures on runoff Implementation of soil and water conservation measures change land cover and alter underlying surface conditions and have direct or indirect impacts on runoff over the past 23 years (Li 2003, Hou et al. 2006). Soil and water conservation projects consisted largely of soil-retaining dams, small reser- voirs and water cellars. One soil-retaining dam and three small reservoirs have a total storage capacity of $300 \mathrm{~m}^{3}$. In addition, there are over 735 water cellars with a total water storage capacity of $14720 \mathrm{~m}^{3}$. Control areas account for $45 \%$ of the watershed with an effective irrigation area of $32.8 \mathrm{~km}^{2}$. With a retention of $90 \%$, reduced runoff due to conservation measures accounts for about $41 \%$ of the total runoff.

Effect of variations of annual water consumption on runoff No major industrial or irrigation facilities exist in the Luoyugou watershed, hence water consumption by industry and agricultural irrigation was not considered. Therefore, the increase of domestic water consumption from natural precipitation and groundwater is the key point to consider. Domestic water consumption $(W)$ is calculated as:

$$
\text { [11] } W=\left(N_{U} \times Q_{U}+N_{R} \times Q_{R}+N_{S L} \times Q_{S L}+N_{L L} \times Q_{L L}\right) \times 365
$$

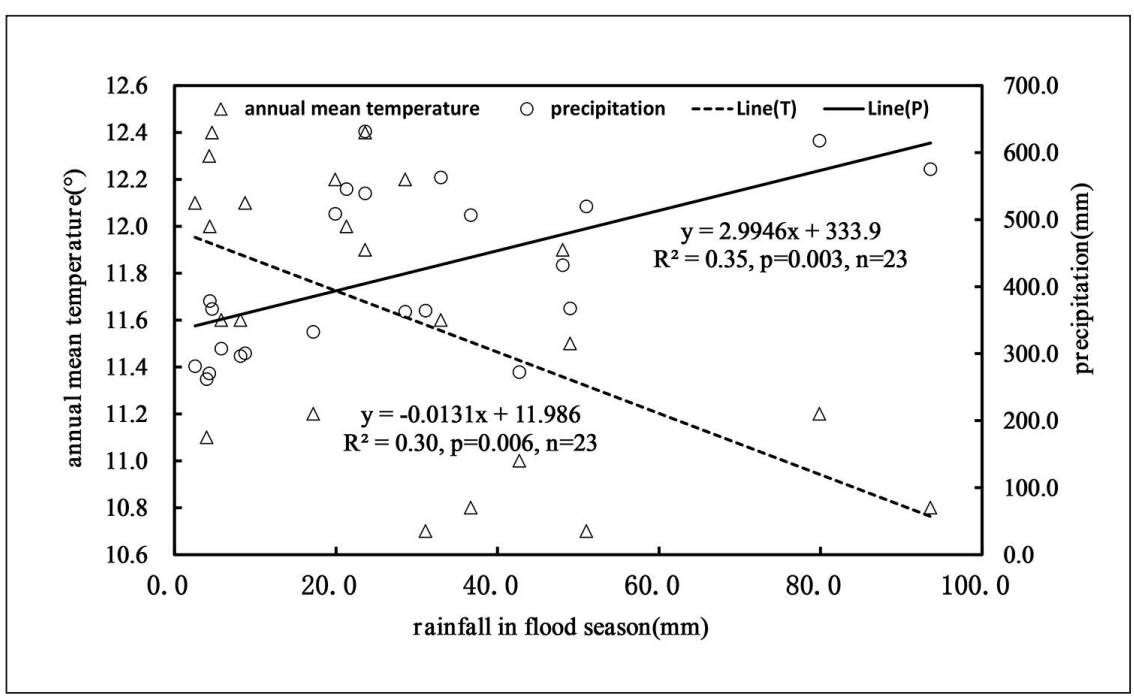

Fig. 6. The relationship between runoff and precipitation, temperature in watershed.

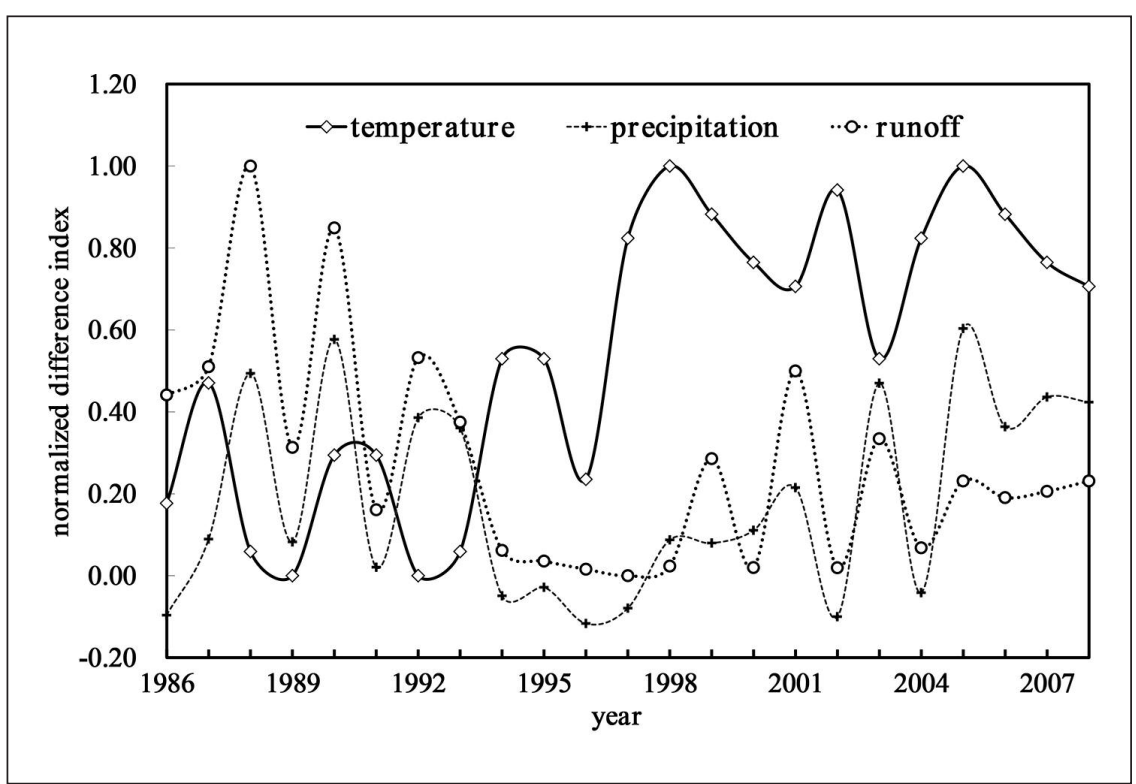

Fig. 7. Changes process of precipitation, temperature and runoff normalized. where $\mathrm{W}$ is the domestic water consumption; $\mathrm{N}_{\mathrm{U}}$ and $\mathrm{N}_{\mathrm{R}}$ represent urban and rural populations; $\mathrm{Q}_{\mathrm{U}}$ and $\mathrm{Q}_{\mathrm{R}}$ are average water demands of urban and rural populations per person per day $(\mathrm{l} / \mathrm{p} / \mathrm{d}) ; \mathrm{N}_{\mathrm{SL}}$ and $\mathrm{N}_{\mathrm{LL}}$ the number of small livestock (pigs, sheep, chickens) and large livestock (cattle, horses, mules, donkeys); $\mathrm{Q}_{\mathrm{SL}}$ and $\mathrm{Q}_{\mathrm{LL}}$ the average water demand of small livestock and large livestock per head per day $(\mathrm{l} / \mathrm{p} / \mathrm{d})$.

Water consumption cited by $\mathrm{Ma}$ and Zheng (2006) and Wang, Z.Y. et al. (2008) is shown in Table 4. Watershed population and livestock numbers are listed in Table 5 (Wu 2010). Based on 2008 data, an analysis of annual water consumption by humans and livestock shows domestic consumption in 2008 was $4.7 \times 10^{5} \mathrm{~m}^{3}$, equivalent to $6.5 \mathrm{~mm}$ of runoff, which accounts for approximately $29 \%$ of the runoff depth in 2008.

Effects of climate change and human activities on evapotranspiration

Fig. 8 shows that the rainfall evapotranspiration double cumulative curves are nearly straight lines, which suggests that differences between the base period (1986-1998) and the compared period (1999-2008) were small. Based on equations 7, 8 and 9, the effects of climate change and human activities on evapotranspiration were calculated. Table 6 shows that human activities account for $91 \%$ of the total evapotranspiration while rainfall accounts for only 9\%. Reforestation, the Slope Land Conversion Program, constructing dams and other measures increased vegetative 
Table 4. The average water demand on the watershed

\begin{tabular}{|c|c|c|c|c|c|c|}
\hline \multirow[b]{2}{*}{ Year } & \multirow{2}{*}{$\begin{array}{l}\text { Urban } \\
\text { (1/p/d) }\end{array}$} & \multirow{2}{*}{$\begin{array}{l}\text { Rural } \\
(\mathbf{l} / \mathbf{p} / \mathbf{d})\end{array}$} & \multirow{2}{*}{$\begin{array}{c}\text { Big } \\
\text { livestock } \\
(\mathbf{l} / \text { head/d) }\end{array}$} & \multicolumn{3}{|c|}{ Small livestock (1/head/d) } \\
\hline & & & & Pig & Sheep & Chicken \\
\hline 1985 & 50 & 15 & 45 & 28 & 42 & 3 \\
\hline 2008 & 87 & 30 & 45 & 28 & 42 & 3 \\
\hline
\end{tabular}

human activities effects on watershed hydrology are neither spatially nor temporally uniform because of its coupling with climate variability ( $\mathrm{Li}$ et al. 2007, Zhang et al. 2009). It is important for watershed management and ecological restoration decisions to understand the water yield regime due to human activities from a watershed given a specific climate condition. Therefore, contributions of climatic variability and human activities to that of annual runoff and actual evapotranspiration in the Luoyugou watershed were evaluated using a multiyear average water balance model and separation evaluation method, respectively. The impacts of different forms of human activities on changes in runoff were also evaluated. Our analysis indicated that annual runoff showed a statistically significant decreasing trend $(p=0.02)$, although precipitation had no significant change (Fig. 2A). This study revealed that the contribution of human activities to the variation in runoff and AET was about $67 \%$ and $91 \%$, respectively, while the remaining was due to climate changes. The implementations of soil and water conservation measures were identified as the strongest contributors $(41 \%)$ for the change in runoff under different human activities from 1986 to 2008, compared with the slope land conversion program (30\%) and increased domestic water
Fig. 8. Double mass curve of annual AET and annual rainfall in the watershed.

15000

$5000 \quad 10000$
cumulative rainfall( $(\mathrm{mm})$

cover and reduced surface runoff and increased evapotranspiration.

\section{Conclusion}

The Loess Plateau region in northwestern China, an area with some of the highest sediment yields in the world, has experienced severe water shortages and soil erosion due to the combined impacts of climate change and human activities during the past decades (Wang, S.P. et al. 2008, Xin et al. 2011). From 1986 to 2008, large-scale sloping farmlands changed into terraces and forest in the study basin. Land use change by consumption (29\%). Therefore, it is inferred that human activities are the main driving force of runoff decrease over the Luoyugou watershed in the past 23 years.

The approach used in this study simply determined contributions of changes for climate change and different forms of human activities to runoff and other hydrological factors, providing quantitative information for stakeholders and decision-makers to make better choices for land and water resource planning and management. More importantly, from the perspective of prevention and control of soil erosion, more attention should be paid to afforestation and soilwater conservation measures for the purpose of reducing soil erosion.

Table 5. Populations and breeding industry structure statistics

\begin{tabular}{lccccccccc}
\hline Year & Rural & Urban & Cattle & Horses & Mules & Donkeys & Pigs & Sheep & Chickens \\
\hline 1985 & 13398 & 3350 & 515 & 77 & 1108 & 390 & 2600 & 3100 \\
2008 & 15386 & 5129 & 642 & 75 & 1257 & 392 & 4286 & 11700 \\
\hline
\end{tabular}

Table 6. Impact of human activities and rainfall variation to evapotranspiration

\begin{tabular}{lccccc}
\hline Period & $\Delta S\left(\mathbf{1 0}^{\mathbf{4}} \mathbf{t}\right)$ & $\Delta S_{\mathbf{1}}\left(\mathbf{1 0}^{\mathbf{4}} \mathbf{t}\right)$ & Contribution (\%) & $\Delta S_{2}\left(\mathbf{1 0}^{\mathbf{4}} \mathbf{t}\right)$ & Contribution $(\%)$ \\
\hline $1986-1998$ & 102.99 & 93.73 & 91.0 & 9.25 & 9.0 \\
$1999-2008$ & & & & & \\
\hline
\end{tabular}




\section{Acknowledgements}

This research was financially supported by the National Natural Science Foundation of China (No.41171028). And was also supported by CFERN\&GENE Award Funds on Ecological Paper.

\section{References}

Allen, R.G., L.S. Pereia and D. Raes. 1998. Crop evapotranspiration guidelines for computing crop water requirements. FAO Irrigation and Drainage Paper 56. Rome, Italy.

Asbjornsen, H., G.R. Goldsmith, M.S. Alvarado-Barrientos and K. Rebel. 2011. Ecohydrological Advances and Applications in Plant-Water Relations Research: A Review. J. Plant Ecol. 4(3): 3-22. Baidu, Inc. (undated). Baidubaike: Converting Linear Equations [online]. Available at http://baike.baidu.com/view/829823.htm.

Bonat, J.V., C.R. Amerman, T.J. Harlukowicz and W.A. Dick. 1997. Impact of coal surface mining on three Ohio watersheds-surface water hydrology. Journal of the American Water Resources Association. 33: 907-917.

Chen, J.F. and X.W. Chen. 2004. Water balance of SWAT model and its application in the Suomo Basin. Acta Sci Nat Uni Pelin 40(2): 265-270.

Gabris, G., A. Kertesz and L. Zambo. 2003. Land use change and gully formation over the last 200 years in a hilly catchment. Catena. 50(2): 151-164.

Hirsch, R.M., J.R. Slack and R.A. Smith.1982. Techniques of Trend Analysis for Monthly Water Quality Data. Water Resources Research.18: 107-121.

Hou, Y.J., J.F. Chen and X.Q. Zheng. 2006. The application and development of Water Cellar - a rainwater catching technology in Qin'an county. Journal of Taiyuan University of Technology. 37(1): 77-79.

Li, H.B., L.F. Luo and E.F. Wood. 2008. Seasonal hydrologic predictions of low-flow conditions over eastern USA during the 2007 drought. Atmos. Sci. Lett. 9(2): 61-66.

Li, L.J., B. Li, L.Q. Liang and J.Y. Li. 2010. Effect of climate change and land use on stream flow in the upper and middle reaches of the Taoer River, northeastern China. For. Stud. China. 12(3): 107-115.

Li, L.J., L. Zhang and H. Wang. 2007. Assessing the impacts of climate variability and human activities on stream flow from Wuding river basin in China. Hydro Process 21: 3485-3491.

Li, M. 2003. Function of Warping Dams in Prevention and Management of Soil and Water Loss in the Middle Yellow River. Yellow River. 25(12):25-27.

Liu, C.M. 1978. The influence of forest covers upon annual runoff in the Loess Plateau of China. Acta Geographica Sinica. 33(2): $112-127$.

Liu, X.Q., J.B. Zhao and X.F. Yu. 2006. Study on the Climatic Warming Drying Trend in the Loess Plateau and the Countermeasures. Arid Zone Research 23(4): 627-631.

Ma, Y., L.D. Chen and C.X. Hu. 2008. Response of Farmer Households to "Grain-for-Green Project" and Quantitative Analysis of Its Affecting Factors. Scientia Geographica Sinica. 28:34-39.
Ma, Z.G. and D.W. Zheng. 2006. Estimation of Rain-collection Amount and Water Utility in a Courtyard in the Ecotone of North Loess Plateau. Research of Soil and Water Conservation.13 (5): 235-237.

Madelene, O. and D.L. Chen. 2006. Land-use change: Impacts of climate variations and policies among small-scale farmers in the Loess Plateau, China. Land Use Policy. 23: 361-371.

Milly, P.C. and K.A. Dunne. 2002. Macroscale water fluxes 2. Water and energy supply control of their inter-annual variability. Water Resource Research 38(10): 241-249.

Tang, K.L. and Y.Z. Chen.1990. Regional Characteristics of Soil Erosion and Its Control Approaches on Loess Plateau Region. pp. 1-38, 94-95, 246. China Science and Technology Press, Beijing.

Wang, G.Q. 2006. Impacts of Climate Change on Hydrology and Water Resources in the Middle Reaches of the Yellow River Basin. $\mathrm{PhD}$ dissertation. Nanjing: Hohai University. $83 \mathrm{p}$.

Wang, G.Q., J.Y. Zhang, R.M. He, N.Q. Jiang and X.A. Jing. 2008. Runoff reduction due to environmental changes in the Sanchuanhe river basin. International Journal of Sediment Research 23: 174-180. Wang, G.S., J. Xia and J. Chen. 2009. Quantification of effects of climate variations and human activities on runoff by a monthly water balance model: A case study of the Chaobai River basin in northern China. Water Resource Research 45 W00A11. doi: 10.1029/ 2007WR006768.

Wang, S.P., Z.Q. Zhang, G. Sun, G.M. Steven. 2008. Long-term stream flow response to climatic variability in the Loess Plateau, China. Journal of the American Water Resources Association 44(5): 1098-1107.

Wang, Z.Y., S.F. Wei and S. Yang. 2008. Probing into Rational Exploration and Utilization of Water Resources in Tianshui City. Gansu Agricultural Science and Technology 6: 38-39.

Wu, F.Z. 2010. Land use change and driving forces research of Luoyugou watershed in Loess Plateau. $\mathrm{PhD}$ dissertation. Beijing Forestry University, Beijing. 13 p.

Wu, J.B. and T.F. Pei. 2002. Effects of sloping fields terraced on runoff and eco-environment in upper reaches of Yangtse River and in upper and middle reaches of Yellow River. Territory And Natural Resources Study. 2: 59-61.

Xin, Z.B., X.X. Yu and X.X. Lu. 2011. Factors controlling sediment yield in China's Loess Plateau. Earth Surf. Process. Landforms 36: 816-826.

Yu, X.X., X.M. Zhang and L.L. Niu. 2009. Simulated multi-scale watershed runoff and sediment production based on GeoWEPP model. International Journal of Sediment Research 24(4): 465-478.

Zhan, C.S., Z.X. Xu, A.Z. Ye, H.B. Su. 2011. LUCC and its impact on run-off yield in the Bai River catchment - upstream of the Miyun Reservoir basin. Journal of Plant Ecology 4(1-2): 61-66.

Zhang, L., W.R. Dawes and G.R. Walker. 2001. The response of mean annual evapotranspiration to vegetation changes at catchment scale. Water Resources Research 37: 701-708.

Zhang, X.P., L. Zhang, Y. Wang and X.M. Mu. 2009. Tempo-spatially responses of the annual stream flow to LUCC in the middle reaches of Yellow River, China. Science of Soil and Water Conservation 7(1): 19-26. 